\title{
Sağlık Bilimlerinde Nitel Araştırmaların Yeri ve Önemi Üzerine Bir Değerlendirme*
}

\author{
An Evaluation of the Place and Importance of Qualitative Research in Health Sciences \\ Yaşar Suveren
}

'Dr. Öğr. Üyesi, Sakarya Üniversitesi Sosyoloji Bölümü. https://orcid.org/0000-0002-8464-0368

Öz

Sağlık bilimleri ve hizmetleri alanlarında göreli olarak daha az başvurulmasına karşın, nitel araştırmalar hızlı bir gelişme göstermiş ve tanınırlığa sahip olmuştur. Nitel araştırmaların çeşitli toplumsal ve kültürel konuların yanı sıra sağlık bilimleri alanlarında da kullanımının giderek arttığı görülmektedir. Daha önceleri nitel araştırma, yalnızca nicel araştırma yöntemini tamamlayan bir bileşeni olarak görülmekteydi ancak nitel araştırmalar artık sosyal ve kültürel boyutlarıyla sağlık araştırmalarında da tanınmakta ve giderek daha fazla kullanılmaktadır. Sağlık bilimleriyle ilgili dergilerde giderek daha fazla nitel araştırma makalesi yayınlanmaktadır. Nicel araştırmadan farklı olarak nitel araştırma, bir olgunun anlamını açıklama yoluyla belirlemeye çalışır. Nitel araştırmalar, katılımcıların deneyimlerine ve görüşlerine vurgu yaparak doğal fenomenlerin anlamlarını anlamaya yardımcı olan kavramlar geliştirmeyi amaçlar. Bu bağlamda nitel araştırmaların sağlıkla ilgili araştırmalarda kullanılması sağlık ve bakım hizmetlerinin geliştirilmesine önemli katkılar sağlayabilir. Bu makale, nitel araştırmaların uygulamasına ilişkin pratik rehberlik sağlama amacını taşımamaktadır. Yine de, sağlık bilimlerinde nitel araştırmanın yerini vurgulamayı ve nitel yöntemleri kullanmanın neden önemli olduğunu vurgulamayı amaçlamaktadır. Bu çerçevede, bu makale ağırıklı olarak nitel araştırmanın tarihsel arka planı, gelişimi, genel felsefi temelleri ve varsayımları, bu alandaki temel kuramsal yaklaşımlar (gömülü teori, fenomenoloji ve etnografi gibi), örneklem seçimi ve veri toplama teknikleri (derinlemesine görüşme, gözlem, dokümantasyon vb.) ve analiz araçları (fenomenoloji, söylem analizi, içerik analizi ve daha fazlası) hakkında temel bilgileri sunmaktadır.

Anahtar Kelimeler: Nitel Araştırma, Nitel Yöntem, Nitel Veri, Nitel Araştırma Tasarımı, Yöntembilim

\section{ABSTRACT}

Although it is applied relatively less in health sciences and services, qualitative research has developed rapidly and has gained recognition. It is seen that the use of qualitative research in the fields of health sciences, as well as various social and cultural issues, is increasing. Previously, qualitative research was only seen as a complementary component to the quantitative research method. Still, qualitative research is now recognized and increasingly used in health research with its social and cultural dimensions. More and more qualitative research articles are being published in health science journals. Unlike quantitative research, qualitative research tries to determine the meaning of a phenomenon through explanation. Qualitative research aims to develop concepts that help understand the meanings of natural phenomena by emphasizing the experiences and views of the participants. In this context, qualitative research in health-related research can make important contributions to the development of health and care services. This article is not intended to provide practical guidance on the application of qualitative research. Nevertheless, it aims to highlight the place of qualitative research in the health sciences and why it is important to use qualitative methods. In this framework, this article mainly focuses on the historical background, development, general philosophical foundations and assumptions of qualitative research, the main theoretical approaches in this field (such as embedded theory, phenomenology, and ethnography), sample selection and data collection techniques (in-depth interview, observation, documentation, etc.) and analysis tools (phenomenology, discourse analysis, content analysis and more).

Keywords: Qualitative Research, Qualitative Method, Qualitative Data, Qualitative Research Design, Methodology

${ }^{*}$ Mersin Üniversitesi Tıp Fakültesi Lokman Hekim Tıp Tarihi ve Folklorik Tıp Dergisi, 2022; 12 (1): $39-48$

DOI: $10.31020 /$ mutftd.1002410

e-ISSN: 1309-8004, ISSN 1309-761X

Geliş Tarihi - Received: 29 Eylül 2021; Kabul Tarihi - Accepted: 30 Kasım 2021

iletişim - Correspondence Author: Yaşar Suveren <ysuveren@sakarya.edu.tr> 


\section{Giriş}

Sağlık bilimleri ve sağlık bakım hizmetleriyle ilgili araştırmalarda göreli olarak nadiren başvurulmasına karşın, nitel araştırmaların hızlı bir gelişme, tanınma ve saygınlık gördüğü söylenebilir. Bu türden araştırmalar, ilgili alanlarda giderek daha fazla kullanılmaktadır. ${ }^{1}$ Daha önceleri nitel araştırmalar, ilgili alana egemen konumdaki nicel araştırma yöntemlerini tamamlayan bir bileşen olarak görülmekteydi. ${ }^{2}$ Bununla birlikte, nitel araştırmacılar sağlık hizmetleri araştırmalarına önemli katkılarda bulunmuş ve sağıı, hastalık, hasta deneyimi, meslekler arası ekiplerin dinamikleri ve bakım sunumunun birçok öğesinin nasıl kavramsallaştırabileceğine ilişkin temel bilgiler sunmuştur. ${ }^{3}$ Bu çalışma, nitel araştırmaya ilişkin pratik bir rehberlik sunma amacını taşımamakla birlikte, sağlık bilimlerinde nitel araştırmanın yerini, önemini ve nitel yöntem ve tekniklerin kullanılmasının neden önemli olduğunu vurgulamayı ve teşvik edici bir zemin sunmayı amaçlamaktadır.

Sağlık bilimlerinde nitel yöntemlerin önemi ve buna duyulan gereksinim, hem sağlıkla ilgili araştırmalarda hem de ilgili uygulamalarda iyileştirme ve geliştirme için yeni araştırma yaklaşımlarının gerekli olduğu gerçeğine dayanmaktadır. ${ }^{1}$ Nitel yöntemlerin örneğin, stres faktörleri ve hastalıkların bireysel önemi, karmaşık bilişsel değerlendirmeler ve bunların yansımaları, yaşam seyri ve biyolojik süreçleri, bunlara etki eden temel faktörlerin sosyal ve biyografik bağlamı ve soruşturulan değişkenler arasındaki karmaşık bağlantıları ele alıp analizinin yapılabileceğine dair birçok argüman ortaya atılmıştır. ${ }^{4}$ Hastalık etiyolojisi, hastalık seyri ve bunun sonuçları ile ilgili birçok nitel araştırma bulunmaktadır. Nitel yöntemlerin sağıık bilimleri ile ilgisi, bu alanda ortaya çıkan yeni soruların birçoğunun nitel yöntemlerle yanıtlanabileceği düşüncesine dayandırılabilir.

\section{Tarihsel Arkaplan}

Faltermaier'e göre nitel yöntemler, "çevresindeki bireye daha fazla odaklanan ve daha çok öznel raporlara ve deneyimlere dayanan araştırma yöntemleri" olarak tanımlanmaktadır. Tüm verilerin yorumlanması, bunların çözümlenmesi ve tekil vakaların daha tümevarımsal ve denetimli bir biçimde anlaşılması yoluyla genelleştirilmesi gerektiği ve daha fazla bilgi oluşturmayı amaçladığı düşünüldüğünde, kavramlar ve kuramlar yaşama daha fazla anlam verirler, umulmadık anlamlara, yorumlara ve bağlantılara daha fazla açıklık sağlarlar" ${ }^{5}$

Nitel araştırma, 1970 'lerde nicel araştırmanın normlarına ve baskın uygulamalarına meydan okumuştur. ${ }^{6}$ Nitel araştırmanın ortaya çıkışı, yirminci yüzyılın başında antropologlar ve sosyologlar tarafından bir araştırma yöntemi olarak ilk kez kullanıldığı bu zamana kadar götürülebilir. Bununla birlikte, bazı araştırmacılar hala nitel araştırma yöntemlerinin o zamandan önce de var olduğuna, ancak hala yapılandırılmamış olduğuna inanmaktadır. Nitel yöntemi kullanan araştırmacılar başlangıçta göreli olarak kuramdan uzak ve belirli bir sisteme dayalı olmadan hareket ediyorlardı. ${ }^{7}$ Buna karşın yine de, ister gettolarda, ister sokaklarda veya tekin olmayan yerlerde olsun, araştırmalarının yoğunlaştığı ve üzerinde çalıştığı doğal ortamlarda insanlarla konuşuyor, sık sık raporlar yazıyor ve insanların yaşam tarzları hakkında gözlemler yapıyorlardı.

Nitel araştırma ve birçok nitel araştırma yaklaşımında 1960'lı yıllarda hızlı ve istikrarlı bir büyüme yaşanmıştır. Örneğin, sembolik etkileşimci bakış açısı ve temellendirilmiş kuramın gelişimi söz konusuydu. ${ }^{8}$ Nitel araştırmalar 1970 'ler ve 1980 'lerde İngiltere'de çeşitli alanlarda bahsedilen yükselişe uygun bir biçimde kullanılmaya başlandı. Bu süreç boyunca, hemşireler gibi sağlık pratisyenleri, meslekleri ve iş yapma biçimleriyle ilgili uygun incelemeler yapmak için nitel araştırmalara başvurdular ve izleyen yıllarda nitel araştırmalar hızla yaygınlaştı. ${ }^{9}$ Crabtree ve Miller, 1992 ve 1999 yıllarında, doktorların nitel araştırmalara yönelik farkındalı̆ını ve bilincini artıran, nitel araştırmanın önemini ve kullanım biçimlerine vurgu yapan 
editoryal bir kitaplar yayınladılar. Bu girişim aynı zamanda Dünya Sağlık Örgütü tarafından "nitel araştırmalarda kavramlar ve yöntemler" başlıklı bir yayının üretilmesine de neden olmuştur.

Nitel araştırma konusunda birçok araştırmacının çeşitli yayınlar yapması sonraki yıllarda bu yaklaşımın hızla benimsenmesine yol açmıştır. Ayrıca çoğu araştırmacının nitel araştırmayı doğalcı (naturalistic) bir inceleme olarak adlandırdığını da belirtmekte yarar var. Nitel araştırma birçok biçim almıştır. Çeşitli araştırmacılar arasında yaklaşımlarında farklııklar söz konusudur. Buna rağmen, bu farklılıkları belirlemek kolay değildir. ${ }^{6}$ Ancak tüm nitel araştırma yaklaşımları, esas olarak yaşanmış deneyimlere, etkileşimlere ve insan diline odaklanır.

Nicel araştırma özellikle sağlık bilimlerinde baskın olmaya devam etse de, nitel araştırma ve yaklaşımlar, giderek daha fazla uygulanmaktadır. Örneğin, British Medical Journal (BMJ), Pope ve Mays'inki gibi nitel yaklaşımları tanıtan bir dizi makale yayınlamıştır. ${ }^{4}$ Nitel yaklaşımları kullanan ve bunları benimsemek için güçlü nedenler sunan çalışmaların sayısı hızla artmakta ve nitel yöntemler yeni incelemeler ve araştırma konuları için çeşitli fırsatlar ve olanaklar sağlamaktadır.

\section{Nitel Araştırmanın Genel Felsefi Temelleri ve Varsayımları}

Nitel araştırmanın felsefi varsayımlarını anlamak, özellikle bunu bir araştırmada dile getirmek ve okurlara sunmak açısından önem taşımaktadır. ${ }^{10} \mathrm{Bu}$ felsefi varsayımlar ve temeller, araştırmacıların araştırma sorununu ve sorularını biçimlendirmelerine yardımcı olur; bu da araştırmacıların bilgiyi veya çeşitli araştırma sorularına yanıtları nasıl aradıklarına rehberlik eder. ${ }^{11}$ Felsefi varsayımlar ayrıca eğitim ve araştırma deneyimlerine derinden kök salmıştır. Dört felsefi varsayım ve temel, araştırmacılara nitel bir çalışma yürütme konusunda rehberlik eder. ${ }^{7}$ Bunlar, ontoloji (gerçekliğin doğası ile olan ilgi), aksiyoloji (araştırmada değerlerin önemi ile olan ilgi), epistemoloji (bilginin ne olduğu ve bilgi iddialarının nasıl doğrulandığı ile olan ilgi) ve son olarak, metodoloji (araştırma süreçleri ile olan ilgi) ile ilgili inançlardır.

Epistemoloji, bildiklerimizi nasıl bildiğimizin incelenmesini içerir ve bilginin güvenilirliğini ve inanılırlığını güvence altına alır. ${ }^{12,13}$ Daha açık bir biçimde söylemek gerekirse epistemoloji, ne yaptığımızı, nasıl ve neden öğrendiğimize ilişkin süreci tanımlamamıza izin verir. Ontolojide odak noktası, dünya ve gerçekliğin doğası hakkında daha fazla bilgi edinmektir. Ontolojide pozitivist gerçeklik nesneldir. Buna göre özgün (otantik) gerçeklik, değişmez doğal neden-sonuç yasaları tarafından belirlenir. ${ }^{13}$ Aksiyolojide ise araştırmalar her adımda araştırmacının değerine bağlıdır. ${ }^{14}$ Başka bir ifadeyle, daha çok araştırmacının araştırmalarından elde ettiği değerlerle ilgilidir.

\section{Kuramsal Yaklaşımlar}

\section{Fenomenolojik Yaklaşım}

Nitel araştırma, araştırmanın konusu olan olguları bütünlüğü ve bağlamı içinde anlamaya odaklanmasıyla nitelendirilir. Fenomenoloji terimi yaygın ve yoğun olarak kullanılmaktadır, buna karşılık önemi belirsiz ve zayıftır. Farklı bilim insanları fenomenolojiye farklı biçimlerde göndermede bulunmaktadırlar. Fenomenoloji, yorumlayıcı kurama, felsefeye, analitik yaklaşıma, önemli bir nitel araştırma geleneğine veya araştırma yöntemleri çerçevesi için bir paradigmaya göndermede bulunabilir. ${ }^{15}$ Spencer ve arkadaşlarına göre fenomenoloji, bireysel deneyimleri veya bakıs açılarını "paranteze alarak" varsayımları ve genellikle verili kabul edilen algılama biçimlerini çalışmaya odaklanan nitel bir araştırma kuramıdır. ${ }^{16}$

Fenomenolojinin temel olarak kabul edilen anlamı, deneyimlerin anlam ve öneminin incelenmesidir. ${ }^{17}$ Yaklaşım, insan deneyiminin ortaklığını temel alır ve deneyimin özünü anlamlandırmaya odaklanır. ${ }^{18}$ Tipik olarak bir fenomen tarafından algılanan öz ise burada temel öneme sahiptir. Incelenen fenomen duygular, ilişkiler, organizasyonlar veya kültürler olabilir. Sağlık bilimlerinin yanı sıra sosyoloji, eğitim, psikoloji, 
hemşirelik ve bakım hizmetleri dahil olmak üzere fenomenoloji söz konusu alanlarda sıklıkla kullanılmaktadır. Al-Busaidi'ye göre, geniş bir fenomenolojik yaklaşımla açıklanan ortak deneyimin özüne odaklanan bir fenomenolojik araştırma yürütmek, insan deneyimini anlamak bakımından önem taşımaktadır. ${ }^{15}$

Fenomenoloji, bireysel bakış açısı ve yorumlamanın önemine güçlü bir vurgu yapar. Seçilmiş örneklemlerde veya tekil vakalarda fenomenolojik teknikler kullanabilir. Görüşme, katılımcı gözlem, eylem araştırması, odak grup toplantıları ve kişisel metinlerin incelenmesi de dahil olmak üzere fenomenolojik araştırma yürütmenin birçok yolu bulunmaktadır. ${ }^{17}$ Ancak fenomenolojik araştırmaların çok büyük miktarda analitik veri ürettiğini de göz önünde bulundurmak gerekmektedir. Sağıık bilimleri araştırmalarında, araştırmacıları bu yaklaşımla tanıştırmak için birçok yararlı yayın bulunmaktadır.

\section{Temellendirilmiş Kuram*}

Fenomenolojik bir araştırmada odak noktası bir eylemin veya oluşumun özünün tanımlanması iken, temellendirilmiş kuram bir oluşumun ya da deneyimin arkasındaki kuramı açıklamaya çalışır. ${ }^{19}$ Temel amacı, sosyal fenomen kuramları ortaya koymaktır: ondan türetilen kanıtların sistematik bir çözümlemesine dayanan daha fazla bilgi ve zengin bir anlayış elde etmek esastır. Mevcut bir hipotezi test etmek veya kanıtlamak için değil, süreci açıklamak için kullanılmalıdır. ${ }^{16}$ Temellendirilmiş kuram, verilerin dikkatli bir çözümlemesini gerektirir. Temellendirilmiş kuram, temel olarak yinelemeli çalışma tasarımı, amaçı örnekleme ve analitik bilgilerin bir sonraki veri toplama döngüsünü besleyen, eşzamanlı veri toplama ve çözümleme döngüleri ile nitelendirilir. Yinelemeli metodolojiye göre örneklem çözümlemenin başında oluşturulmaz, ancak araştırma ilerledikçe dikkatli ve amaç yönelimli bir biçimde seçilir. Glaser ve Strauss, 1967 'de temellendirilmiş kuramın ilk savunucularındandı ancak o zamandan bu yana söz konusu kurama ilişkin her biri kendi süreçlerini ve standartlarını ortaya koyan çeşitli girişimler de söz konusu olmuştur. ${ }^{17}$ Ancak, temellendirilmiş kuramın genellikle çok kötü bir biçimde yapıldığını ve dergilerin, bu kuramı kullanan çok sayıda araştırmayı reddettiğini veya araştırmaların yetersiz bir biçimde uygulandığını da belirtmekte yarar var.

\section{Etnografik Yaklaşım}

Etnografik kuram araştırmacının, araştırma amaç ve hedefleri ile ilişkili olarak ortaya çıkan, nedenleri ve sorunları bulmak, kültürleri ve alandaki zorlukları bağlamsallaştırmak için katılımcıların ortamına girmesini gerektirir. Araştırmacı, etnografik çalışmada bir grubun yapısını ve işlevini inceler. Akrabalık bir yapıyı örneklerken; işlev, davranışı etkileyen ve düzenleyen ilişki kalıplarına atıfta bulunur. ${ }^{16}$ Etnografik araştırma, belirli bir topluluğun/grubun kültürel ve toplumsal sisteminin özelliklerini betimlemek için o topluluğun bütünsel bir resmini ortaya koymayı amaçlar. Bu amaçla, ilgili topluluğun tarihi, din, ekonomi, siyaset ve çevre gibi faktörlerin tümü araştırma kapsamına girebilir. ${ }^{20}$

Veri toplama teknikleri etnografik çalışmalarda farklılık göstermekle birlikte, en yaygın olanları gözlem ve görüşmelerdir. ${ }^{17}$ Görüşmelere veya anketlere bağlı kalmak yerine araştırmacı, çevreyi ilk elden bazen bir "katılımcı gözlemci" olarak gözlemler ve bu, araştırmacının kamuya açık sosyal pratiklere, ancak genellikle "gizlenen" sosyal pratiklere dair deneysel bir içgörü kazanmasını sağlar. ${ }^{19}$ Cleland, Savage'a atıf yaparak, etnoloji teriminin günümüzde herhangi bir küçük ölçekli günlük sosyal araştırmada kullanılabileceğini ve bir bireyin anlam ve açıklamalarına odaklanan sayısız yaklaşım kullanıldığını belirtmektedir. ${ }^{17}$

\footnotetext{
*ingilizce'de Grounded Theory olarak adlandırılmaktadır. Türkçe'de söz konusu kuram ilgili alanyazında 'Temellendirilmiş Kuram' veya 'Gömülü Kuram' olarak da kullanılmaktadır. Bizim bu metindeki tercihimiz Temellendirilmiş Kuram’ı kullanmak yönündedir ve bunun özel ve özgül bir yanı bulunmamaktadır.
} 
Etnografi, sağlık ve hastalıkla ilgili davranışların anlaşılmasını sağlayan ve bu konularla ilgili sorun ve soruların ortaya çıktıkları bağlamda görülmesine izin veren, sağlığa yönelik inançları ve uygulamaları anlamak için de kullanılmıştır. ${ }^{20}$ Ayrıca kültürler arası etnografik çalışmalarda da bir artış söz konusudur. Bu durum etnografik araştırmaların içerik ve biçimine de etki etmiştir. Örneğin, uluslararası kalkınma ajansları vb. kurumlar tarafından finanse edilen araştırmalar, kısa erimli etnografik çalışmalar biçiminde gerçekleştirilmektedir.

\section{Örneklem Seçimi ve Veri Toplama Teknikleri}

Nitel yönteme dayalı araştırmalar, sağlık, hastalık ve sağlık hizmetleri alanlarındaki deneyimler hakkında nicel olmayan verileri toplayarak ve bunları sistematik olarak çözümleyerek sağlık risklerini azaltmaya yardımcı olabilir. ${ }^{21} \mathrm{Bu}$ yönteme dayalı araştırmalar sağıı bilimleri alanındaki araştırmacılara hasta deneyimlerini ve bakış açılarını anlamaya, araştırma tasarımında ve yürütülmesinde doğru bir biçimde bütünleştirmeye ve hastalara eşit tedavi olanaklarının sunulmasında yol göstericilik sağlayabilir. ${ }^{22}$

\section{Örneklem Seçimi}

Örnekleme, araştırmacıların her bir bireyi incelemeden popülasyonun bir alt kümesinin sonuçlarını çözümleyerek ilgili popülasyon hakkında çıkarım yapılmasına olanak tanıyan bir araştırma tekniğidir. Örneklem, büyük bir popülasyonu temsil eden hedef popülasyonun yansız bir alt kümesidir. Örneklem, bir çalışma ortamında tüm bireylerle çalışmaktan kaynaklanabilecek kaynak ve zamandan tasarruf etmeye yardımcı olur ve ayrıca yüksek nitelikte bilgi edinmeyi kolaylaştırır. Bununla birlikte, gerçek bir bağıntı (korelasyon) bulma olasılığı ile yeterince büyük bir örneklem büyüklüğü arasında bir dengenin de sağlanması gerekir.

Nitel araştırmalarda örneklem, incelenen fenomenle ilgili koşullarda yaşayan belirli niteliklere sahip, belirli insan gruplarını veya her ikisini birden bulmayı amaçlar. Örneğin, bakteriyel menenjitte erken kortikosteroid uygulamasının yararlarının az gelişmiş dünya için de geçerli olup olmadığını test etmek için yapılan tıbbi bir deneyde, gelişmiş dünyadaki örneklem ve ölçüm nasıl yapılacaktır? ${ }^{23}$

Nitel araştırmalarda çeşitli adlarla anılan örnekleme teknikleri bulunsa da bunlar temelde iki ana örnekleme tekniğinin çeşitlemeleridir. Bu iki temel teknik şunlardır: maksimum çeşitlilik ve benzeşik (homojen) örneklemedir. Nitel bir araştırmacı, bir fenomende büyük çeşitlenmeleri sergileyen ortamları veya bireyleri arayarak bir fenomeni incelemeye çalıştığında, maksimum çeşitlilik örneklemesine başvurur. Bu, katılımcıları seçmek için yaş, kültürel geçmiş veya sınıf gibi önceden belirlenmiş ölçütlerin var olduğu anlamına gelir. Benzeşik örnekleme söz konusu olduğunda ise, araştırmacı bazı alt grupları derinlemesine tanımlayacağı küçük benzeşik bir örneklem seçer. Bir görüşmecinin kapsamlı ve uzun bir görüşme yapabilme yeteneği, nitel araştırma için örneklem büyüklüğünü belirleyen önemli bir etkendir. Nitel araştırmacılar genellikle, derinlik için kapsamı feda etmek durumunda kalırlar ve çoğu kez de zaman ve kaynak kısıtlamaları ile karşılaşırlar.

Amerikan Halk Sağlığı Derneği İstatistik Bölümü Halk Sağlığı İstatistikleri Örnekleme Teknikleri Komitesi'ne göre, örnekleme kamu sağlığı konusunda verimli bir biçimde kullanılabilir. Örnekleme teknik ve uygulamalarının bilinmemesi, kamu sağlığı çalışmalarında değerli bir aracın daha etkin bir biçimde kullanılmasını engellemiştir. ${ }^{23}$ Seçimi iyi yapılmış bir örnekleme, yeni bir sağlık programı ve uygulamasının planlanması, belirli bir bölgede yaşayan insanlar hakkında sağlık bilgisi elde edilmesi, önerilen bir sağlık prosedürünün etkinliğini test edilmesi ve sonuçlarının değerlendirilmesi için etkili bir biçimde kullanılabilir. 


\section{Nitel Veri Toplama}

Nitel veri toplama teknikleri genellikle araştırma amaçları bakımından üç ana kategoriye ayrılır: 1) Görüşmeler (bireysel veya grup), 2) Gözlem teknikleri ve 3) Araştırmanın değerlendirilmesi.

\section{Görüşme}

Bilgi toplamak için kullanılan en tipik teknik görüşmedir. Üç tür görüşme biçimi bulunmaktadır: bunlar sırasıyla yapılandırılmış, yarı yapılandırılmış ve yapılandııımamış görüşmedir. Fakat bunlar alanyazında yapılandırılmış, bilgilendirilmiş (informed) ve yönlendirilmiş (guided) olarak da tanımlanabilmektedir. ${ }^{21}$ Nitel araştırmalarda görüşmeler, araştırma kapsamındaki belirli konularla ilgili belirli temaların daha derinden anlaşılmasına yardımcı olur. Genellikle bire bir veya grup halinde (odak grupları) yapılır. Görüşmeler, araştıılan konuya, kültürel bakış açılarına ve araştırma amaç ve hedeflerine bağlı olarak düzenlenebilir.

Doktorların, hemşirelerin ve diğer sağlık çalışanlarının, yaşam ve hastalık fenomenleri hakkındaki anlayışlarını bilimsel olarak genişletmeleri gerektiği söylenebilir. Çünkü hastaları sıklıkla hastalık ve yaşam fenomenini deneyimler ve bunu sembolize ederler. ${ }^{3}$ Bu nedenle, araştırmacıların ve klinisyenlerin söz konusu deneyimleri ve sembolleştirmelerini kavramanın etkili yollarından biri olan görüşme tekniğine hakim olmaları önem taşımaktadır. Hasta sağlığından sorumlu hemşirelerin veya bir doktorun hastalarıyla görüşmeler yaparak geçmişlerini ayrıntılı bir şekilde gözden geçirmelerine ve olası hastalık müdahale teknikleri hakkında etraflıca bilgi sahibi olmalarına gereksinim vardır. Görüşmeler ayrıca paydaşlardan gerekli bilgileri elde etmek için çeşitli tıp araştırmacıları tarafından politika oluşturma yönelimli araştırmalarda da kullanılmaktadır.

Yarı yapılandırılmış görüşme daha yaygın olarak kullanılmaktadır. Bu görüşme türü, deneyimleri ve tutumları araştırmak için açık uçlu sorular için gevşek bir yapı sağlayan esnek bir tema kılavuzuna dayanmaktadır. Bu görüşme türü, bilim insanlarının yeni alanlara erişmesini ve daha fazla bilgi üretmesini sağlayan üstünlüklere sahiptir. Ayrıca araştırmacılara bilgi verenlerle etkili bir ilişki geliştirmede de yardımcı olur. $^{8}$

Yarı yapılandırımış görüşmeler, bireylerin kendileri hakkında düşünce ve açıklamalar üretmesine fırsat verir ve araştırmacının ummadığı kimi bilgileri de keşfetmesine olanak tanır. Bu görüşme türü, genellikle insanların olaylara ve yaşam deneyimlerine bakış açıları, anlayışları ve yorumları hakkında bilgi edinmek için kullanııır. ${ }^{24}$ Ancak, çözümleme sürecinin sorunlarına ek olarak, bu tür görüşmelerin araştırmacının görüşme ortamı üzerindeki denetimini zayıflattığı ve çözümleme için daha fazla zaman aldığı bildirilmektedir.

Yapılandırılmamış görüşmeler ise, konudan konuya, temadan temaya değişen ve genellikle önceki soruların yanıtlarına bağlı olan sorulara dayanır ve başından itibaren herhangi bir belirlenmiş soru veya soru kümesi söz konusu değildir. ${ }^{25}$ Görüşmeler, özellikle araştırma hastalara sunulan bakım öğeleri ve ilgili uygulamaların etkileri ve hastalar arasında bunlardan kaynaklı farklılıklara odaklanıyorsa ve yine bu öğelerle ilgili mevcut kanıtlar yetersizse, sağı̆ araştırmaları için doğru bir araçtır. ${ }^{26}$

Nitel araştırmalarda görüşmeler özünde, birincil veri toplama tekniğidir ve araştırmacının konuyla etkileşimini içerir. Genellikle istenen popülasyondan seçilen bir örneklem içinde gerçekleştirilirler. Açık uçludurlar ve sohbet havasındadırlar. ${ }^{27}$ Görüşme verileri aşağıda değinileceği üzere yine nitel teknikler kullanılarak çözümlenir. Klinik bir profesyonel, her zamanki tedavisi nedeniyle hastalıktan mustarip olan bireylerle etkileşime girebilir ve nitel bir araştırmacı olarak hareket etmesine karşın, klinik tanımlamalarda olduğu gibi tedavi ortamlarında standart yanıtlar aramasına karşın, sayısız ve ardışık sorular aracılığıyla veri toplayabilir. Görüşme tekniğinin ise bunun en etkin yollarından biri olduğu söylenmelidir. 
Nitel araştırmalarda odak grup görüşmeleri de bir veri toplama tekniği olarak yaygın bir biçimde kullanılmaktadır. Belirli bir çalışma sorusunu veya konusunu tartışmak için özenle seçilmiş sınırlı sayıda bir grup insanla etkileşime girmeyi içerir. ${ }^{27}$ Genellikle araştırma amaçlı ve politika saptama yönelimli kararlar almak için kullanılırlar ve geleneksel akademide pek de iyi bir itibara sahip değildirler. Bununla birlikte, algılar, değerler ve inançlarla bağlantılı sağlıkla ilgili niteliksel veri toplamak için güçlü bir araç olduğu söylenebilir. ${ }^{8}$ Denscombe'a göre, araştırmacılar odak gruplarını insanların düşüncelerine, davranışlarına ilişkin daha derin bir kavrayışa sahip olmak ve ayrıca nasıl davrandıklarını ve düşündüklerini anlamak için kullanırlar, bu da "neden", "ne", "nasıl" ve "neden olmasın" gibi araştırma sorularına yanıt verme fırsatı sunar. ${ }^{25}$ Odak grup görüşmelerinin üstünlüğü, görüşme yapmak için aynı miktarda zamana sahip daha fazla bireyle görüşme yapmaya fırsat vermesinden kaynaklanır.

\section{Gözlem}

Gözlem, doğal ortamlardaki davranışlar ve ilişkiler hakkında bilgi edinmek için bireylerin ve olayların ayrıntılı bir biçimde gözlemlenmesini içerir. ${ }^{28}$ Klinisyenler hastalar üzerinde gözlem teknikleri kullanırlar ve epidemiyologlar hastalığın seyrini gözlemlemek için eğitilirler. Nitel araştırmacılar, doğal ortamlardaki davranış veya etkileşimler hakkında bilgi edinmek için bireyleri, olayları ve ortamları sistematik olarak izlerler. ${ }^{29}$ Gözlem, araştırma aracı olarak araştırmacının düşüncelerini somutlaştırmasına yardımcı olur. "Alana git" ifadesini içerir ve görülenleri tanımlamaya ve çözümleme etmeye olanak verir. Yöntem, sağlık bakım ortamlarında aydınlatıcı olmuştur, ancak deneyimsiz ve hazırlıksız araştırmacılar için tuzaklar da yok değildir. Çalışmanın amacı kültürel özellikleri keşfetmekse, durum gizlilik, belirsizlik veya örtüklükler gösteriyorsa veya alandaki konular diğer gruplardan önemli ölçüde farklı görünüyorsa etkili bir teknik sayılabilir. Davranış veya durum raporlarının aksine, gözlemler belirli bir duruma ve gerçek davranışa ilişkin içgörüler için değerlidir. ${ }^{30}$ Gözlem, katılımcı veya katılımcı olmayan biçiminde sınıflandırılır. Katılımcı gözlemde araştırmacı, gözlenen ortamın bir parçasıdır. Bir hemşirenin yoğun bakım biriminde çalışması buna örnek verilebilir. Katılımcı olmayan gözlemde araştırmacı, gözlemlenen ortamın dışındadır. Örneğin, ortamda bulunurlar fakat oranın bir parçası değildirler ve varlıklarıyla ortam veya durumu değiştirmezler.

Gözlemlerden elde edilen yazılı alan notları daha sonra gözlem protokollerine dönüştürülür. Birden fazla gözlemci katıldıysa, alan notları ayrı ayrı alınır, ancak notlar daha sonra tek bir protokolde birleştirebilirler. ${ }^{11}$ Gözlem yapmanın üstünlük taşıyan özellikleri arasında araştırmacı ile araştırılan arasındaki boşluğun en aza indirilmesi, potansiyel olarak ilgili konu ve sorunların belirlenmesine fırsat sağlaması ve araştırma sorununun gerçek dünya boyutuna ilişkin daha derin kavrayışlar sunma olasılıkları sayılabilir.

\section{Belgelere Dayalı Veri Toplama (Dokümantasyon)}

Yazılı belgeler veya çeşitli kurumlardan alınan her türden kayıtlar ve tarihsel ve bireysel günlükler gibi kamuya açık belgeler de diğer veri toplama teknikleri gibi, araştırılan grubun yaşamlarını ve deneyimlerini anlamak için yardımcı bir veri kaynağı olarak kullanılabilir. ${ }^{21}$ Belgelere dayalı çözümleme, araştırmalar için önemli bir araçtır ve araştırılan fenomenin incelenmesinde metodolojik bileşimin ayrılmaz bir parçasıdır. Veri toplama ve çözümleme sırasında araştırma sorularını ele almak için belgeler de kullanabilir. ${ }^{31}$ Sağılık politikası üzerine yakın zamanda yapılan bir araştırma, bunun birden fazla yolla yapabileceğini ortaya koymaktadır. Politika yönelimli belgeler genellikle içeriği açıklamak veya mevcut politikalardaki belirli sağlık sorunları yaklaşımlarını kategorize etmek için değerlendirilmiştir, örneğin ABD'nin boğulmayı önleme kaynaklarına ilişkin belge incelemeleri veya Güney Afrika'daki ölümcül alkol spektrum bozukluklarının belgelere dayalı incelenmesi gibi. ${ }^{32}$ Farklı durumlarda da, örneğin, Yeni Zelanda'daki toplum sağlığı konseylerinin işleyişini çözümlemede internet kaynakları ve gazeteler gibi araçlar sağlık politikalarını araştırmak için politika dışı belgeler olarak kullanılmıştır. ${ }^{33}$ 


\section{Nitel Araştırmada Çözümleme Araçları}

Bir tıp araştırmacısının veri çözümlemesinde ele aldığı sorun veya konuya ilişkin çıkarımlarda bulunabilmesi, çözümleme yordamlarına hâkim olabilmesine bağlıdır. Çalışma tasarımının ve veri çözümlemesinin başarısız bir şekilde uygulanması, yetersiz veya anlam taşımayan sonuçlara ulaşmasına neden açabilir. Sağılı araştırmalarında veri çözümlemesine ilişkin üç nitel yöntem vardır: fenomenoloji, söylem çözümlemesi ve içerik çözümlemesi.

\section{Fenomenolojik Çözümleme}

Daha önce de belirtildiği gibi fenomenolojide, gerçeklik somutlaşmış deneyim yoluyla anlaşııır. Fenomenolojik çözümlemeciler, özgül bir olay veya durumun anlamını ve ortaklaşan niteliklerini veya özlerini belirlemek için bireysel deneyimleri incelerler. Bu çözümlemeler, fenomenolojik araştırmalar yürütüldüğünde yaşanmış deneyimin anlamı hakkında fikir veren temaları açıklamaları bakımından zengin bir içeriğe sahiptirler. Genellikle temalara dayalı notlar veya öyküler biçiminde yazılırlar.

Starks ve Brown'ın andığı böylesi bir çözümlemede örneğin, birinci basamak doktorlarının doktor-hasta ilişkisinin belirsiz bir klinik karar verme sürecini nasıl deneyimledikleri çözümlenmiştir. ${ }^{34}$ Fenomenolojik çözümleme şu çıkarıma yol açmıştır: birinci basamak doktorlarının profesyonel kimliği çok yönlü ve çok boyutludur. Bu durum onları görevleri ile yükümlülükleri arasında bırakarak gerilim ve içsel çatışma yaşamalarına yol açmış ve bu da doktorları çoğu zaman gerilim, belirsizlik, öfke ve düşmanlık duyguları içinde bırakmıştır.

\section{Söylem Çözümlemesi}

Bu çözümleme yordamı, dilbilim, edebiyat eleştirisi ve göstergebilimden ortaya çıkmıştır. İnsanların dil yoluyla bireysel, toplumsal ve politik hedeflere nasıl ulaştığının ortaya konulması bu yaklaşımın odak noktasıdır. Gerçeklik hakkındaki görüşümüz dil tarafından hem dolayımlanır hem de kurulur. Toplumsal roller de bir kişinin kimliği tarafından tanımlanır. Dil, bireylerin kimliklerini de ifade ettikleri ana düzenektir. Katılımcıların öykülerini ve diğer materyalleri kullanan söylem çözümlemesi, insanların amaçlarına ulaşmak için dili nasıl kullandıklarını ortaya çıkarır. Dilin dikkatli bir biçimde çözümlenmesi, toplumsal normların kurulmasını ve korunma biçimlerini, bireysel ve kolektif kimliklerin kuruluşunu ve sosyal ve politik etkileşimin içeriğini aydınlatabilir. Söylemi çözümlemek, dil pratiklerinin tarihsel evriminin izini sürmeyi ve dilin dinamik nitelikli kültürel, politik ve toplumsal alanları nasıl etkilediğini ve aydınlattığını incelemeyi içerir. ${ }^{34}$ Söylem çözümlemesinin sonuçları tipik olarak yararcı (pragmatist) bir niyete sahip olsa da, genellikle daha fazla analitik soyutlamalar yapabilmeyi gerektirir.

Starks ve Brown'ın verdiği örneğe atıfla, dikkatimizi, söylem çözümlemesi merceği aracılığıyla hastalarla karşılaştıklarında birinci basamak doktorlarının sayısız alternatif rolünün söylemde nasıl üretildiği ve müzakere edildiğine odaklayabiliriz. Tıp ve halk sağlığı söylemleri, doktorların ve hastaların rollerini biçimlendirmektedir. ${ }^{34}$ Söz konusu bu roller hakkındaki egemen söylem doktorları tanı konusunda uzman, kanıta dayalı tıp bilgilerini uygulayan yetkin bilim insanları ve hastalarına danışman olarak kurmakta veya biçimlendirmektedir. Bu söylemi bilen ve ayırdında olanlar meslekte yüksek itibar görürler. Fakat öte yandan birinci basamak doktorları, bilimin tüm yanıtlara ve çözümlere sahip olmadığı gerçeğinin de farkındadırlar.

\section{İçerik Çözümlemesi}

İçerik çözümlemesi, belirli sözcüklerin, düşüncelerin veya kavramların nitel çözümlenmesidir. Bir araştırmacı, içerik çözümlemesini kullanarak belirli sözcükleri, konuları veya kavramları ölçebilir ve inceleyebilir. ${ }^{35}$ Önyargı veya tarafgirlik aramak için araştırmacılar bir metinde kullanılan dili inceleyebilirler. 
Sonuçta, araştırmacılar metinlerin içindeki anlamlar, yazar(lar), izleyiciler ve hatta metnin özgün biçimlenişi, kültürü ve zamanı hakkında sonuçlara varabilirler. İçerik çözümlemesi, kararlılığı, tekrarlanabilirliği ve doğruluğu (metin sınıflandırmasının istatistiksel olarak bir standarda veya norma ne ölçüde karşılık gelmesi) nedeniyle güvenilirdir.

\section{Sonuç}

Günümüzde sağlık bilimleri alanındaki bazı meslekler, sağlıkla ilgili konuları birey-çevre etkileşim modeli bağlamında ele almayı tercih etmektedir. ${ }^{29}$ Artan sayıda bilim insanı artık sağlıklı veya hasta insanları, çevresel ortamda tehlikeli uyaranlara tepki veren yalnız ve tecrit edilmiş birileri olarak görmek yerine, belirli bir toplumsal çevrede var olan, yaşamları boyunca anlamlı değişiklikler yapan, potansiyel olarak bilinçli varlıklar olarak görmektedir. ${ }^{36}$ Değişen bir çevre değişen bireyin meta modelidir. Bu bağlamda, yeni birçok sağlık araştırması sorusu sorulmalı ve değişen birey ile değişen çevre arasındaki etkileşimleri anlamak bakımından yenilikçi modelleri dikkate alan yenilikçi araştırma yöntem ve tekniklerine açık olunmalıdır. Sağlık bilimleri alanında nitel araştırmalar bu bağlamda metin boyunca da vurgulanmaya çalışıldığı üzere bunun için elverişli araçlar ve fırsatlar sunabilir. Bu bağlamda, nitel araştırma yöntemleri sağlıkla ilgili araştırmalarda giderek daha fazla kabul görmektedir. Nitel sağlık bilimleri ve hizmetleri araştırmaları, araştırmacıların nicel yöntemlerin kolayca yanıtlayamadığı soruları yanıtlamasına olanak tanır. Ayrıca incelenen olguyu, çalışıldığı kültür veya ortam bağlamında anlamaya çalışır ve bu nedenle kültürel olarak daha kabul edilebilir nicel araştırma araçlarının geliştirilmesine de yardımcı olabilir. Bununla birlikte, onlarca yıldır sağlıkla ilgili araştırmalar nicel yöntemlere dayalı olarak gerçekleştirildiğinden, alanda çalışan pratisyen ve araştırmacıların artık kısmen aşımış olduğu söylenebilirse de, kalıplaşmış yargı, önyargı ve katılıklarını aşmak zorlayııı bir öğe olarak ortada durmaktadır. Giderek daha fazla aranan, başvurulan ve uygulanan nitel yöntemin tanıtılması, onu sağlık bilimleri ve hizmetlerinde kullanmaya çalışan araştırmacıların kuramsal temellerini, metodolojisini ve çözümleme araç ve tekniklerini daha yakından bilmelerini ve anlamalarını gerektirmektedir.

\section{Bilgi}

Makale ile ilgili herhangi bir çıkar çatışması söz konusu değildir.

\section{Kaynaklar}

1. Chafe R. The Value of Qualitative Description in Health Services and Policy Research. Healthc Policy. 2017;12(3):12-8.

2. Cleland J. Exploring versus measuring: considering the fundamental differences between qualitative and quantitative research. In: Researching Medical Education. Cleland J and Durning S J, editors. West Sussex: John Wiley \& Sons Ltd; 2015. pp:3-12.

3. May S G, Roach M, Murphy R. The Importance of Qualitative Research in Enhancing Understanding of Treatment Decisions, Outcomes, and Value Assessment. Journal of Clinical Pathways 2021;7(4):31-3.

4. Mays N, Pope C. Quality in qualitative health research. In Qualitative Research in Health Care. West Sussex: John Wiley \& Sons Ltd; 2016. pp:1-11.

5. Faltermaier T. Why public health research needs qualitative approaches: Subjects and methods in change. Eupha 1997; 7(4): 357-63.

6. Aspers $P$, Corte U. What is qualitative in qualitative research. Qual Sociol 2019;42(2): 139-160.

7. Collins CS, Stockton CM. The central role of theory in qualitative research. IJQM 2018;17(1):1-10.

8. Mohajan H. Qualitative Research Methodology in social Sciences and Related Subjects. Jedep 2018;7(1):23-48.

9. Rolfe DE, et al. Using qualitative Health Research methods to improve patient and public involvement and engagement in research. Res Involv Engagem 2018;4(1):1-8.

10. Busetto L, Wick W, Gumbinger C. How to use and assess qualitative research methods. 2020; Neurol Res Pract 2:14.

11. Khan S. Qualitative Research Method: Grounded Theory. IJBM 2014;9(11):224-33.

12. Kivunja C, Kuyini AB. Understanding and Applying Research Paradigms in Educational Contexts. IJHE 2017;6(5):26-41.

13. Ahmed A. Ontological, epistemological and methodological assumptions: Qualitative versus quantitative. No Title [Internet]. [erişim

27/08/2021]

Erişim

adresi: 
https://www.researchgate.net/publication/267736833_Ontological_Epistemological_and_Methodological_Assumptions_Qualit ative_Versus_Quantitative/link/597f254b0f7e9b8802ebabc8/download

14. Lee N, Lings I. Doing business research: A guide to theory and practice. 1st ed. Sage Publications; 2008.

15. Al-Busaidi Z Q. Qualitative Research and its Uses in Health Care. Sultan Qaboos Univ Med J 2008;8(1):11-9.

16. Spencer R, Pryce, JM, Walsh J. Philosophical approaches to qualitative research. In The Oxford Handbook of Qualitative Research. Oxford; 2001. pp:111-142.

17. Cleland JA. The qualitative orientation in medical education research. Korean J Med Educ 2017;29(2):61-71.

18. Vagle MD. Crafting phenomenological research. London: Routledge; 2016.

19. Singh A. Significant Study of Qualitative Research In Health Care. 2021;7, No Title [Internet]. [erişim tarihi 13/09/2021] Erişim adresi: https://sciforum.net/paper/view/conference/9234.

20. Richardson JC, Liddle J. Where does good quality qualitative health care research get published? PHCR\&D 2017; 18(05): 515-21.

21. Korstjens I, Moser A. Practical guidance to qualitative research. Part 2: Context, research questions and designs. EJGP 2017; 23(1): 274-79.

22. Patricia M. Qualitative research in medical education. In Oxford Textbook of Medical Education. Oxford; 2013. pp:638-647.

23. Suresh G, Suresh K, Thomas S. Design, data analysis and sampling techniques for clinical research. AIAN 2011; 14(4):287-90.

24. Leavy P. Introduction to the Oxford handbook of qualitative research. 2nd edition. In The Oxford Handbook of Qualitative Research, Oxford; 2020. pp:xxii-20.

25. Denscombe M. The good research guide: For small-scale social research projects. Open University Press; London; 2007.

26. Easterby-Smith M, Shenxue L, Jean B. Research Methods for Organizational Learning: The Transatlantic Gap. Management Learning 2019; 40(4):439-47.

27. Fisher C, Buglear J. Researching and writing a dissertation: an essential guide for business students, 3rd ed. (NY): Prentice Hall; 2010.

28. Lemon L. Applying a Mindfulness Practice to Qualitative Data Collection. TQR 2017;22(12):3305-13.

29. PLoS Medicine Editors. Qualitative research: Understanding patients' needs and experiences. PLoS Med 2007;4(8):e258.

30. Kozleski EB. The Uses of Qualitative Research: Powerful Methods to Inform Evidence-Based Practice in Education. RPSD 2017;42(1):19-32.

31. Katchmarchi AB, Taliaferro AR, Kipfer HJ. A document analysis of drowning prevention education resources in the United States. Int J Inj Contr Saf Promot 2018;25:78-84.

32. Adebiyi BO, Mukumbang FC, Beytell A-M. To what extent is fetal alcohol spectrum disorder considered in policy-related documents in South Africa? A document review. Health Res Policy Syst 2019;17(46):1-12.

33. Gurung G, Derrett S, Gauld R. The role and functions of community health councils in New Zealand's health system: a document analysis. N Z Med J 2020;133(1510):70-82.

34. Starks H, Brown TS. Choose your method: A comparison of phenomenology, discourse analysis and grounded theory. QHR 2007;17(10):1372-80.

35. Hsieh HH, Shannon E. Three Approaches to Qualitative Content Analysis. QHR 2005;15(9):1277-88.

36. Griffin RH, Nunn CL. Community structure and the spread of infectious disease in primate social networks. Evol Ecol 2012; 26:779-800. 